\title{
Spoznajmo retorične sposobnosti
}

Tatjana Zidar

\begin{abstract}
Kadar poslušamo in opazujemo govornike, ki pred nami razpredajo bolj ali manj zanimive teme in misli, lahko opazujemo naše odzive oziroma reakcije: nas navdušijo, ostanemo hladni, se razburimo... - kar pestra paleta izzvanih čustev.
\end{abstract}

Smo se že kdaj vprašali, kaj je tisto, kar v nas zbudi odobravanje ali nasprotovanje? Kaj pravzaprav uporablja govornik, kaj vsebuje oziroma združuje njegov govor, da nas pritegne ali izzove naše nasprotovanje? Kako bi lahko te elemente spoznali, se jih naučili in začeli uporabljati?

Res je, da nekateri (pri nas verjetno kar večina) oblikujejo svoje govorne nastope povsem intuitivno, zgolj po lastni presoji. Koliko so pri tem uspešni, je prav gotovo stvar naravne danosti in spleta okoliščin. Moramo pritrditi, da nekaterim kljub vsemu dobro uspeva!

Pa vendar! Znanje retorike bo zelo pripomoglo, da se izognemo nepotrebnim spodrsljajem. Najpogostejše napake so predvsem nejasni cilji (kaj pravzaprav hočemo doseči, kaj povedati), neprilagojenost referenčnemu okviru občinstva (ne upoštevamo, kdo so poslušalci, kaj od nas pričakujejo, kakšne so njihove želje, pričakovanja, zahteve), šibki in nepravilni argumenti, ki ne prepričajo, lahko celo užalijo poslušalce, neprimeren način podajanja (kadar vsebino beremo). Pri nebesednem nastopu pa je vsekakor največji problem trema in nezaupanje vase, nepravilna drža telesa, toge, plahe ali pa avtoritativne kretnje, odsotnost pogledov (prekinemo tok komunikacije), uporabljamo cel kup mašil (ee, amam, hm), razne vzdihljaje, predolge premore...

\section{Analihični pristop}

Do kakovostnega in učinkovitega govornega nastopa pripomore analitično učenje posameznih elementov retorike; v nadaljevanju učenja pa je treba zgraditi sintezo osvojenih znanj in spretnosti. Najprej se je torej treba zavedati naslednjih področij in jih izuriti:

- vsebinski del

(oblikovanje in razporeditev snovi v smiselno in trdno celoto pomen dobrega uvoda in zaključnih besed, poznavanje možnosti za graditev dramatičnosti, izbor pravega besedišča, s čimer pritegnemo pozornost občinstva, kaj pomeni vrh govora, oblikovanje argumentacije, gladkost in jasnost pripovedovanja...)

\section{- nebesedni del}

(pomen in povečanje učinka nastopa $\mathrm{z}$ gestikulacijo, mimiko in telesno držo, pomen glasu - intonacija, barva, jakost, tempo...)

- psihična priprava (spominska izurjenost - primerne vaje za boljši spomin, sprostitvene tehnike - vaje za premagovanje treme, pravilno dihanje in moč koncentracije)

- izvedba in analiza nastopa

(sinteza vseh elementov $\mathrm{v}$ učinkovito celoto - v kakovosten/dober govorni nastop).

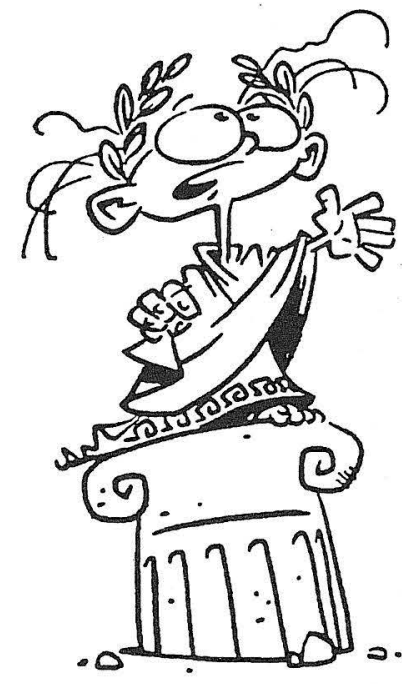

Vsekakor je za pridobivanje retoričnega znanja najboljše izkustveno učenje $v$ manjših skupinah (največ 15), kjer lahko udeleženci menjajo vlogo poslušalcev in nastopajočih. S konkretnimi nastopi se utrjujejo $\mathrm{v}$ novih spretnostih, kot poslušalci pa razvijajo kritičen odnos do povedane vsebine in izvedbe nastopa.

\section{Keako Začefi}

Temeljno izhodišče pri učenju veščin javnega nastopanja naj bodo elementi nebesednega sporočanja oziroma komuniciranja. Ob spoznavanju teh spretnosti (in praktičnih preizkusih) poskušamo premagati največjo oviro - strah. Poskušamo obvladati telo in glas; šele nato vso pozornost usmerimo v vsebinski del sporočila.

Naše vodilo naj bo misel, da nas ljudje gledajo, poslušajo in tudi občutijo. Ne smemo pozabiti, da pri poslušalcih najprej izzovemo čustvene reakcije - navdušenje, jezo, odobravanje, zavračanje, mirnost..., šele nato sledi razumsko vrednotenje vsebine. Zato je treba spoznati načine, kako poslušalce pritegnemo vidno, slušno ter $\mathrm{v}$ njih prebudimo občutke in čustva; nato pa sledi spoj z vsebinsko zgradbo govornega nastopa.

\section{Nebesedna sporočila}

Pomembno je, da se naučimo komunicirati oziroma pravilno uporabljati pomagala s teh treh temeljnih področij. Človek namreč komunicira prek različnih kanalov: prek vidnega, slušnega in kinestetičnega. Bolj ko jih bomo znali »odpreti«, bolj bomo govorno zanimivi. Zato se tudi učenje retorike začne pri spoznavanju in uporabi teh področij. Lahko rečemo, da poskušamo povečati svojo karizmo: bolj ko bomo ljudi pritegnili vidno in slušno ter jih ganili kinestetično, bolj bomo postali karizmatični. Vsak govornik naj bi bil karizmatična osebnost ( $\mathrm{v}$ pozitivnem smislu seveda).

\section{Komuniciramo vidno}

Da bo naš vizualni nastop zaživel, je treba uskladiti telesno držo, mimiko obraza in pa gestikulacijo. Kako si pri tem poma- 
gamo? Kaj moramo vedeti? Naše učenje oziroma opazovanje in ocenjevanje naj poteka po naslednji razpredelnici: položaj glave, pogledi, mimika (izraz obraza), drža ramen (naj bo sproščena in ravna), uporaba kretenj, telesna drža (ravna, zravnana) in položaj nog.

\section{Telesna drža}

Bistvena stvar je, da se za-

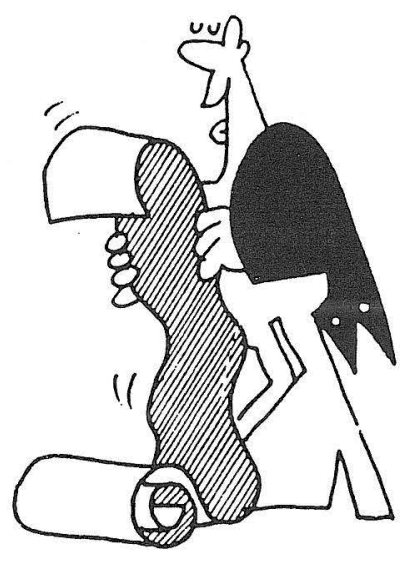
vedamo svoje telesne drže. Ko govorimo, stojmo. Če sedimo, je zaradi ukleščenega prsnega koša doseg glasu precej omejen, dosti manjši. Ustvariti moramo občutek gotovosti in prepričljivosti, kar dosežemo s pravilnim težiščem (stojimo na obeh nogah, energija se mora enakomerno porazdeliti; nikar ne prestopajmo iz ene noge na drugo). S prostorskim premikom lahko še bolj nazorno pokažemo spremembo vsebine oziroma prehod iz ene $\mathrm{v}$ drugo misel - $\mathrm{z}$ gibom roke, korakom..., za večjo jasnost in učinkovitost si pomagamo še $z$ spremembo glasu - sprememba tempa, jakosti, intonacije, barve...

\section{Položaj glave}

Tudi položaj glave ima pomembno izrazno moč. Če potiskamo glavo preveč nazaj, nehote izražamo vzvišenost, oholost in prevzetnost, $s$ čimer lahko pri poslušalcih vzbudimo odklonilno razpoloženje. Kadar pa nam začne lesti $\mathrm{k}$ prsim, razkrivamo svojo negotovost, nemoč; zato je najboljši żravnan položaj.

\section{Pogledi}

Zelo pomemben je očesni stik. Preden spregovorimo, si lahko vzamemo vsaj 20 sekund časa, da s poslušalci navežemo oziroma vzpostavimo komunikacijo. Kam pa naj pravzaprav gledamo? Na seminarjih retorike bomo lahko temeljito izurili t. i. poslovni in družabni pogled. Kadar govorimo manjšemu številu ljudi (do 6), bo najučinkoviteje, če vsakega posameznika gledamo v točko med njegovimi očmi (temu rečemo poslovni pogled; je jasen, natančen, konkreten). Ko se število poslušalcev poveča (na seminarju govorimo vsem udeležencem, sicer pa naj ne bi bilo število večje od 30 poslušalcev), si lahko izberemo družabni pogled (navidezni trikotnik - oči in usta). Toda pazimo! Bolj ko bomo širili trikotnik od ust navzdol, bolj bo naš pogled postajal intimen (bolj globoko bomo gledali), kar pa lahko pri poslušalcih (! predvsem poslušalkah) izzove nelagodje ali celo obrambno razpoloženje. Kadar pa bomo spregovorili še večjemu številu ljudi, bo najbolje, če jih razdelimo na tri dele: središčni, levi in desni. Pogled najprej usmerimo v središčni del poslušalcev in ga širimo na levo in desno stran.

Zavedati pa se moramo, da je velika razlika, ali ljudi samo gledamo ali jih tudi vidimo. Vsak poslušalec, pa naj jih bo le 5 ali pa 400 , mora imeti občutek, da govorimo njemu - zato moramo občinstvo videti pred seboj (premalo bo, če jo bomo samo gledali) in z njo ohraniti očesni stik do konca.

\section{Gestikulacija}

Celoto našega vizualnega nastopa pa bodo dopolnile še naše kretnje. Težko bi »predpisali«, kakšne gibe naj kot govorniki uporabljamo. Gestikulacija je odvisna od osebnosti, temperamenta, namena (v kakšni vlogi nastopamo - kot politiki, kot odvetniki (tu je uporaba kretenj manjša), učitelji, direktorji...) in od poslušalcev (množica (gestikulacija se poveča), sodniki (se zmanjša)...). Lahko pritrdimo Vatovcu (1984, str. 251), ki ugotavlja, da je pravilen postopek gestikulacije, ko se kretnja pojavi hip pred spregovorjeno besedo, trenutek za tem pa se že prilepi govorjeni besedi in jo spremlja, vendar ne kot osrednji dejavnik, temveč kot nemo soizrazilo, ki dopolnjuje glavni izrazni način glasovno izraženo besedo.

Kljub vsemu pa moramo pri spretnostih gestikuliranja nekatere stvari vendarle poznati! Najboljše, pa tudi najlepše so tiste kretnje, ki se pojavljajo od pasu do ramen; kadar smo precej »razvneti« pa do višine oči. Za dobro komunikacijo si pomagamo s t. i. pozitivnimi kretnjami: odprta dlan ali pa most: navpično iztegnjene dlani v razmiku vsaj $10 \mathrm{~cm}$ - kot da hočemo zgraditi neko vez, most med nami kot govorniki in poslušalci. Izogibajmo pa se stiskanju pesti, žuganju s prsti, prekrižanim rokam (pomenijo barikado), tudi prstom, sklenjenim v molitev, in zvonu (prsti obeh rok se še vedno stikajo, le razširimo jih).

\section{Položaj nog}

Bodimo pozorni, da jih ne bomo držali prekrižano (tudi to pomeni barikado), ampak upoštevajmo staro igralsko pravilo - eno nogo držimo rahlo pred drugo ali pa eno zraven druge - le gležnja naj se ne dotikata.

\section{Komuniciramo slušno}

O glasovnih elementih smo govorili že $\mathrm{v}$ prejšnji številki (1995, št. 3-4, str. 23-26). Pri učenju oziroma opazovanju in ocenjevanju nam bo torej pomagala naslednja razpredelnica: hitrost, jakost, izgovarjava, razvade (odpravimo mašila: ee, amam, hmm...), moteče vzdihe in vzklike, premore (naj se pojavijo ob

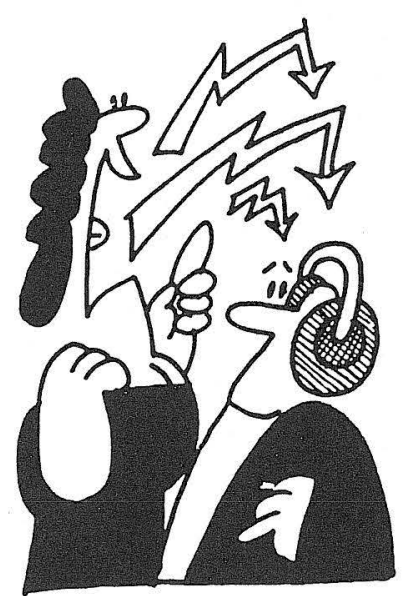
koncu izrečene misli, nikakor ne sredi nje; premor sledi izdihu - da lahko mirno vdihnemo; pazimo - vedno govorimo, ko izdihavamo, potem sledi premor, nov globok vdih in spet nadaljujemo $\mathrm{z}$ govorjenjem), sprememba barve (uporabljajmo barvne odtenke glasu - od šaljivih, resnobnih tonov, pa navdušenih, veselih (odvisno od vsebine), morda malo ogorčenih in spet pomirjajočih..., uporaba intonacije (izogibajmo se monotonosti, spomnimo se na uporabo kadence, spreminjajmo višino)

\section{Komuniciramo kinestetično}

Kinestetični kanal pa nam bo pomagal, da v poslušalcih prebudimo občutke, čustva, vtise. Kot da bi hoteli povedati, da čutimo s tistim, o čemer govorimo, in hočemo ta občutja prenesti tudi njim. Zato govorimo zavzeto, prepričljivo, navdušeno (kadar to zahteva oziroma dopušča vsebina; sodni govor ima gotovo drugačno izhodišče). Stari Grki so od govornikov zahtevali, da je njihov nastop izžareval dostojnost, poštenost in prijaznost. Se je danes kaj spremenilo? Čisto nič! 
Verjeti moramo v tisto, kar govorimo; predvsem pa verjeti vase. Opazujmo torej svojo izrazno moč prepričljivosti, zavzetosti in navdušenosti (kar je seveda odvisno od vsebine in namena govora).

To pa je najtežji element pri učenju retorike. Kako postati prepričljiv? Najučinkoviteje preizkusimo (in kasneje odpravimo svoje nelagodje) tako, da začnemo oblikovati vsebinski del govornega nastopa in ga ob zavedanju in upoštevanju vseh treh kanalov glasno povemo pred udeleženci tečaja oziroma seminarja.

\section{Kako podahi vsebino govora poslušalcem?}

Najpomembnejša je izurjenost, da se »usposobimo« za prosto podajanje vsebine; torej svojih govorov ne bomo brali. Pisni jezik zelo težko učinkovito prenesemo, »transponiramo v govor oziroma na slušno področje. Gotovo se vsi spomnimo dolgočasnih trenutkov, ko smo poslušali govornike ali predavatelje, ki so svoje teme prebrali. Tempo takega govora je navadno prehiter, ni naravnih premorov, vnaprej pripravljen zapis izzveni tuje, celo nenaravno, slišimo celo množico novih podatkov in informacij, ki jih zaradi njihove količine in hitrosti njihove predstavitve ne moremo sprejeti, kaj šele, da bi si jih zapomnili. Stavki so dolgi, zato dostikrat vsebinsko nerazumljivi.

M. Beyer (1993) opozarja, da so vdihi sredstva za postavljanje govornih ločil. Ker zrak, ki ga dobimo z enim vdihom, zadostuje v povprečju za dve do štiri sekunde, lahko v tem času pokažemo, podamo informacijo. Sledi ponovni vdih in ob izdihu spet oblikujemo nov sklop vsebine, ki si jo poslušalci lahko zapomnijo. Kaj pa se zgodi, če beremo? Misli, stavke smo že oblikovali, zato lahko govorimo hitreje. Vsaj osem do deset sekund nam ni treba oblikovati nove vsebine, novih misli, premori se nehote pojavijo na nepravih mestih, sledimo namreč pisnim ločilom (vejica, pika....), ne pa naravnim ločilom vdiha in izdiha. Poslušalci toliko novih podatkov in informacij (v 8 do 10 sek.) ne morejo sprejeti. Prvi del (od 2 do 4 sek.) bodo lahko sprejeli, drugi pa bo uničil tok komuniciranja; nit sprejemanja bo pretrgana. Tu je treba opozoriti, da upoštevajmo staro pravilo retorike: stavki naj bodo kratki, jasni in konkretni; tako si bomo najlaže predstavljali, kako si sledijo intervali sprejemanja. V štirih sekundah lahko povemo en stavek, ki predstavlja zaključeno celoto. Če sledimo naravi govorjenja, bomo nehote naredili premor, vdihnili in nadaljevali. Kadar pa bo stavek dolg, bodo poslušalci lahko sprejeli le prvi del, drugi pa se bo razgubil; vsebina in pomen bosta izgubljena. Zato govorov ne beremo, ampak sledimo naravnemu toku govorjenja, ki naj bo gladko in razločno.

Veliko bolj prepričljivo je torej, da si uredimo alinee, morda gesla. Še boljšo organizacijo celotnega besedila pa bomo razvili ob uporabi miselnih vzorcev. Pred seboj bomo imeli celotno zgradbo, celotno hierarhijo misli in idej. Glavni pojmi, besede ali gesla izhajajo iz središča, razcepijo se v nadaljnje podpojme; vsebinsko so podrejeni predhodnim.

Pri prostem govorjenju je stik z občinstvom popolnoma drugačen. Vsebina, prikaz in govornik so prepričljiva celota, ki jo je treba ohranjati do konca govornega nastopa; predvsem pa prilagajati referenčnemu okviru poslušalcev. Napisani govor predstavlja tujek, ki se mu je treba ves čas prilagajati, občinstvo potisnemo v drugi plan.

Ne bo odveč, če si bomo že na tečaju retorike poskušali živo predstavljati, da govorimo določenemu krogu poslušalcev (za vajo lahko isto vsebino prilagajamo različnim skupinam poslušalcev - otroci, strokovnjaki določenega področja, množica različnih izobrazbenih skupin...). Še preden oblikujemo miselni vzorec, odgovorimo torej na naslednja vprašanja:

- kdo so naši poslušalci,

- kaj želim doseči (naš končni cilj govora),

- koliko časa bom imel na razpolago,

(za vajo bosta dve minuti povsem dovolj; sicer pa naj govornik nikoli ne govori več kot 20 minut, v tem času lahko razvije največ tri ideje, pa še tu naj bo ena glavna in dve stranski, ki prvo samo podkrepita oziroma dopolnjujeta),

- kaj je ključni problem, ki ga bom kot govornik/ca skušal/a razložiti in poiskati možne rešitve,

- kje so vzroki za nastalo situacijo,

- kaj potrebujem za oblikovanje svojih argumentov: podatki, informacije institucij, podjetij..., mnenja strokovnjakov - bodo potrebni intervjuji, splošno mnenje - predvsem mnenje poslušal-

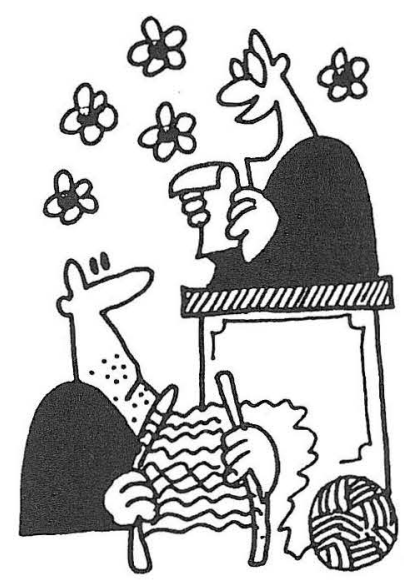
cev, ki ga bomo lahko dobili z anketami ali pa že z znanimi javnomnenjskimi raziskavami, strokovni članki, ugotovitve raziskav...).

Za naš končni uspeh pa so pomembna še naslednja vprašanja:

- kaj je pomembno za občinstvo, kakšne so njihove želje, cilji, potrebe...,

- s kakšnimi argumenti bi dosegli soglasje, kateri so torej nesporni argumenti,

- kateri argumenti bodo deležni ugovorov (vsekakor potrebujemo ankete in javnomnenjske raziskave, intervjuje vplivnih osebnosti...).

Vrnimo se $\mathrm{k}$ miselnim vzorcem. Ko nam bosta sestava poslušalcev, predvsem pa naš končni cilj povsem jasna, oblikujmo svoj miselni vzorec: iz naslova si sledijo glavni deli govora, ki se hierarhično delijo v podtočke. Na vsaki črti naj bo le majhno geslo, še bolje ena sama beseda.

Izhodiščne možnosti zgradbe smo si ogledali že v prejšnji številki (1995, št. 3-4, str. 23-26).

\section{Najpomembnejšse smernice}

Pri uporabi in učenju prostega govora je najpomembnejše:

1. Zgraditi je treba smiselno in trdno celoto, kjer misli prehajajo spontano druga $v$ drugo (govorimo o jasni naraciji); predstavimo jih jasno, gladko in razumljivo.

2. Ves čas je treba spremljati odziv občinstva; kaj storimo, če začutimo nelagodnost, nestrinjanje občinstva (upoštevamo pravila pritrdilnih odgovorov, od nespornega se počasi pomikamo $\mathrm{k}$ spornim točkam).

3. Vsebinsko zgradbo dopolnimo oziroma okrepimo z nebesednimi sporočili (uporaba vidnega, slušnega in kinestetičnega kanala).

Kako torej izurimo svoje spretnosti jasnega in gladkega govorjenja ob uporabi miselnega vzorca? $\mathrm{Za}$ vajo si lahko pomagamo, da iz linearno zapisanega članka (časopisni članek, kratka novela, črtica...) uredimo svoj miselni vzorec. Linearno vsebino razgradimo na posamezne miselne enote in jih hierarhično vnesemo na črte oziroma veje miselnega vzorca. Potem pa novo nasta- 
lo členitev glasno predstavimo. Pri tem opazujemo našo gladkost pripovedovanja, oblikovanje jasnih miselnih sklopov in stavčne strukture povedanega (kratki, jasni in konkretni stavki). Ne pozabimo na nebesedna sporočila! Kasneje pa poskušajmo izbrati lastne teme, ki jih vnesemo v zgradbo miselnega vzorca in glasno povemo udeležencem tečaja oziroma našim poslušalcem.

Miselni vzorec nam bo pomagal tudi pri spremljanju in sprejemanju odzivov občinstva. Ne bomo ujeti v že vnaprej oblikovane in zapisane teze in ideje, $v$ linearno zapisano besedilo, ki bi nam preprečevalo naravno govorjenje (nepravilne premore, prehiter tempo, vsiljena uporaba barve in intonacije - prilagajati bi se morali besedilu, ne pa občinstvu), ovirano bi bilo tudi vzpostavljanje in vodenje komunikacije $\mathrm{z}$ vizualnimi sredstvi (pretrgan očesni stik, zaprta drža, če bi držali liste, zaradi branja bi imeli upognjena ramena in sklonjeno glavo...).

\section{Odzivi občinstva}

$\mathrm{Ob}$ nebesednih izraznih sredstvih pa je treba razmisliti tudi o uporabi pravega besedišča, ki nam bo pomagalo do večjega strinjanja oziroma soglasja občinstva. Za izhodišče lahko vzamemo Perlmanovo trditev (1993), da je cilj argumentacije predvsem spodbuditi ali povečati strinjanje poslušalcev $s$ tezami, ki jih govornik zagovarja oziroma razlaga.

Pomagamo si $\mathrm{z}$ elementi Sokratove metode - majevtike. Začnemo torej s tistim delom vsebine, s katero občinstvo povsem soglaša (izvabimo pritrdilne odgovore). Več pritrdilnih odgovorov bomo do-

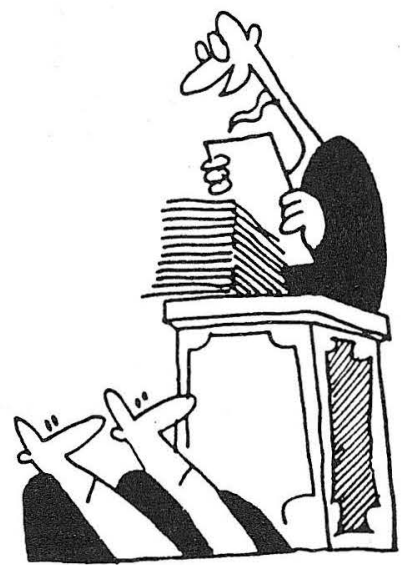
bili, bolj bomo poslušalce pri-

tegnili $\mathrm{k}$ pozornemu poslušanju in $\mathrm{k}$ večji naklonjenosti za naš končni predlog, naš cilj govora. Pomagamo si z vprašanji, ki zahtevajo odgovore, s katerimi se občinstvo povsem strinja (poiščemo zaprta vprašanja, kar bi pomenilo, da sprašujemo tako, da občinstvo pritrdi $\mathrm{z}$ da, mi pa potem odgovor razširimo $\mathrm{z}$ našo vsebino, ki nikakor ne sme izzvati kakega odklonilnega razpoloženja). Znani so Lincolnovi govori, v katerih je prve pol ure govoril tako, da so se poslušalci strinjali s sleherno njegovo besedo. Ko je ugotovil, da je vse brez izjeme pridobil na svojo stran, pa je pričel s spornimi vprašanji oziroma temami. Upošteval je torej pravilo, da nikoli ne začnemo $\mathrm{z}$ argumenti, za katere že vnaprej vemo, da jih poslušalci ne bodo tako zlahka sprejeli.

\section{Najprej čustva}

Govorili smo že, da se poslušalci na naš nastop odzivajo najprej s čustvi, šele nato sledi razumska odločitev. Že stari Grki so upoštevali pravilo: začnimo s patosom in končajmo z logosom. Zato oblikujmo svoj vsebinski del nastopa tako, da začnemo s spodbujanjem čustev, ki pa ga nadgradimo s spodbujanjem razuma (zato najprej začnemo s pritrdilnimi odgovori in nespornimi argumenti; občinstvo mora začutiti, da jo povsem sprejemamo, spoznati mora našo naklonjenost in zavzetost, šele nato bo pripravljena poslušati sporne argumente). Kar predstavljajmo si, kako bi reagirali, če bi govornik začel svoj nastop s trditvijo, da nam bo dokazal, kako se motimo?!
Izhodišče vsebinskega dela je prav gotovo spretnost, kako povečamo strinjanje in soglasje občinstva $\mathrm{z}$ našimi argumenti. Možnosti je še veliko: kako oblikujemo vsebino, kadar je potrebno rešiti sporno situacijo, kako si pri tem pomagamo s šeststopenjskim reševanjem konfliktne situacije, kako ob deduktivnih in induktivnih metodah začnemo uporabljati tudi operativne postopke, s katerimi si pomagamo, da se izognemo neposrednemu nesoglasju občinstva...

Tatjana Zidar

diplomirana dramaturginja, samostojna kulturna delavka

\section{Liferafura}

Beyer, M. (1993): Retorika in moderatorika (zapiski predavanj). Radovljica, Ministrstvo za šolstvo in šport, Glotta Nova.

Beyer, M. (1993): Nevrolingvistično programiranje (zapiski predavanj). Bled,

Ljubljana, Ministrstvo za šolstvo in šport, Glotta Nova.

Beyer, M. (1995): Možganija. Ljubljana, Glotta Nova.

Carnegie, D. (1985): Kako se naučiš javno nastopati in govoriti. Ljubljana,

Zagreb, Delo, Prosveta.

Greene, R. (1993): Nov način komuniciranja. Ljubljana, Alpha center.

King, L. (1994): How to talk to anyone, anytime, anywhere. New York. Crown publishers, inc.

Maier, K., Weber, M. (1987): Erfolg durch Superlearning. München, Wilchelm Heyne Verlag.

Pease, A. (1986): Govorica telesa. Ljubljana, Samozaložba.

Perelman, C. (1990): Kraljestvo retorike. Ljubljana, Znanstveno in publicistično središče.

Škarić, I. (1988): U potrazi za izgubljenim govorom. Zagreb, Školska knjiga. Thiele, A. (1995): O govorniški spretnosti. Ljubljana, Gospodarski vestnik. Valentine, N. (1993): Speaking in public. London, Penguin books.

Vatovec, F. (1984): Javno govorništvo. Trst, Založba tržaškega tiska. 